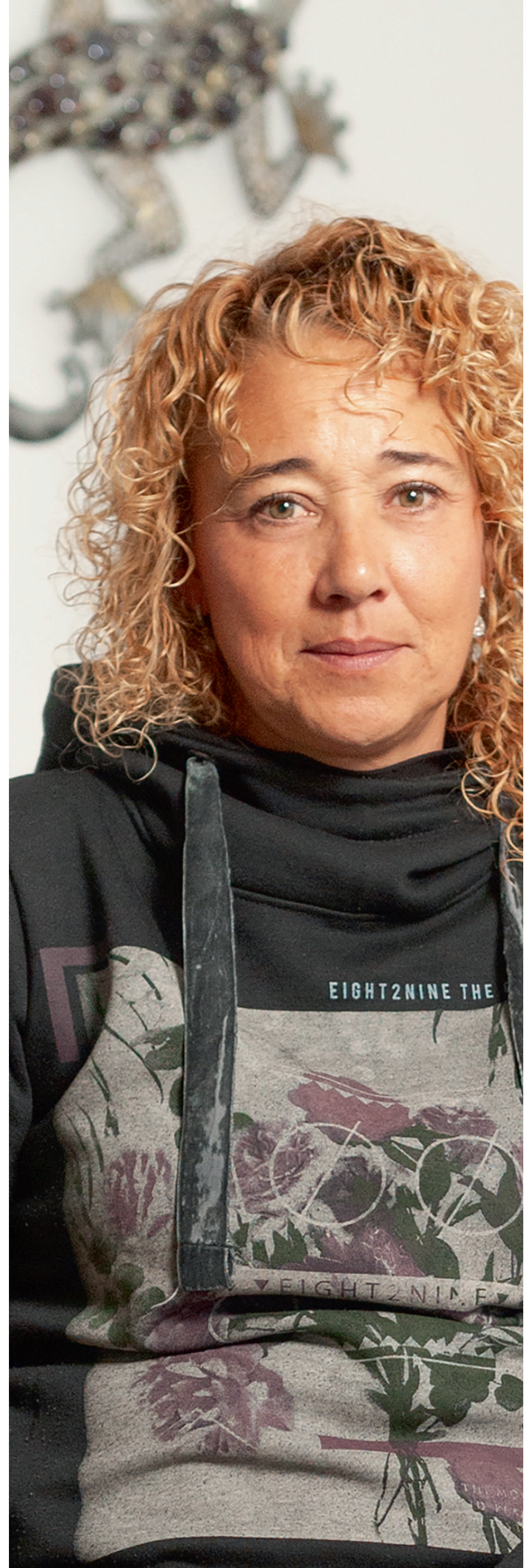




\section{'Er is te weinig gevoel van urgentie en verpleegkundigen zijn daar de dupe van'}

Verpleegkundig specialist Nienke Ipenburg en antropoloog Ginny Mooy zijn betrokken bij het Red Team, dat de Nederlandse overheid tegenspraak wil bieden bij het coronacrisisbeleid. Hoe zien zij de coronapandemie en de rol van de verpleegkundige hierin?

tekst Alexia Hageman fotografie Arno Massee

Het Red Team ${ }^{1}$ : je hebt er ongetwijfeld van gehoord. Het bestaat uit een groep experts die het Outbreak Management Team (OMT) en het kabinet onafhankelijke tegenspraak en advies willen geven over het coronabeleid. Volgens het Red Team is dat in tijden van crisis noodzakelijk om tunnelvisie bij de beleidsmaker en regering te voorkomen. De kern van het Red Team bestaat uit 12 leden. Zij worden omgeven door een 'denktank', met onder andere leerkrachten, verpleegkundigen, IT'ers en psychologen.

Het Red Team is ontstaan vanuit individuele contacten en niet door een centraal orgaan samengesteld. Verpleegkundig specialist Nienke Ipenburg en antropoloog Ginny Mooy zijn beiden lid van het kernteam en hopen zo met hun kennis en expertise een bijdrage te leveren aan de bestrijding van covid-19.

Wat vinden jullie van de manier waarop Nederland de pandemie probeert te beteugelen?

'Vanuit mijn antropologische expertise kijk ik naar de manier waarop beleid en gedrag elkaar beïnvloeden', zegt Mooy. 'En ik maak me grote zorgen. In Nederland ontbreekt er vanaf het begin al een gevoel van urgentie, zowel bij het kabinet als bij de bevolking. De manier waarop er vanuit de overheid wordt gecommuniceerd is daar debet aan.' Dat kan Nienke Ipenburg beamen. 'Er wordt alleen gestuurd op ziekenhuiscijfers, maar daar heeft de thuiszorg niets aan. Het lijkt alsof ze niet zien dat veel zorg thuis wordt gegeven, of in zorghotels, of op een cohort. Intussen accepteert het kabinet een hoge mate van besmetting, maar we weten nog helemaal niet wat de gevolgen van het ziektebeeld (op de lange termijn) zijn.'

Hoe gaat de Nederlandse bevolking om met de pandemie? 'Als de urgentie bij de regering ontbreekt, reageert de bevolking ook met laconiek gedrag', zegt Mooy. 'Dat ligt mede aan onze cultuur. In vergelijking met andere landen hebben wij best een laconieke houding ten aanzien van onze gezondheid en we investeren er weinig in. Wij vinden het heel normaal om met een verkoudheid of griep naar het werk te gaan, in Azië bijvoorbeeld zijn mensen zich er veel bewuster van dat je dan besmettelijke ziekten over kan brengen.' Mooy werkte in Sierra Leone tijdens de Ebola-epidemie in 2014 en ziet duidelijke paralellen in de manier van reageren van de bevolking op boodschappen vanuit de regering. Als de overheid communiceert dat het niet zo erg is, nemen mensen ook meer risico's. Zodra er bijvoorbeeld hoop komt in de vorm van 'goed' nieuws, ontspant men. Eerst was dat met hydroxychloroquine, toen met bloedplasma en nu zie je dat 
ook met de komst van een vaccin. Iedere keer als er een wondermiddel wordt gepresenteerd, gaan mensen zich anders gedragen, alsof we er al zijn. Het is heel moeilijk om dat gedrag om te buigen.'

\section{Wat merken verpleegkundigen van het regeringsbeleid?}

Ipenburg: 'Binnen het Red Team probeer ik vanuit mijn expertise context aan de cijfers te geven. En de boodschap uit te dragen dat elke actie en maatregel van het kabinet direct voelbaar is in de zorg. Ik probeer uit te leggen hoe het gaat in de zorg. Het verhaal van verpleegkundigen moet verteld worden en daarmee hoop ik dat er ook essentiële zaken veranderen in het beleid. Zo houd ik mij bezig met de situaties rond de persoonlijke beschermingsmiddelen, het blootleggen van de hoge werkdruk in de wijk- en huisartsenzorg en de rol van zorgverzekeraars in deze pandemie. Maar ik vertel vooral dat covid niets nieuws heeft gebracht, maar alleen pijnlijk blootlegt wat al bestond aan problemen in de zorg. Dat is nodig, want uit de communicatie vanuit de regering blijkt op geen enkele manier dat deze begrijpt wat er speelt op de werkvloer. Veel zorgpersoneel voelt zich in de steek gelaten. Verpleegkundigen en verzorgenden zijn ook niet meegenomen in het 'lessons learned' traject van VWS (na de eerste golf).'

Hoe gaan zorgverleners om met deze pandemie?

Ipenburg: 'Ik zie 2 groepen zorgverleners: een groep die zich heel bewust is van het virus en de gevolgen ervan, en een groep in de we-zien-wel-modus.' Volgens Ipenburg heeft dat ook te maken met het feit dat de ene zorginstelling in een brandhaard zit en het in de andere zorginstelling relatief rustig is. 'De kunst is om in dat laatste geval niet weg te kijken, maar je af te vragen waarom het elders niet goed gaat en wat je kunt doen om te helpen. Ga het gesprek met elkaar aan. Ook al is dat een collega aan de andere kant van het land. Je kunt zeggen: "Ik heb het niet zo zwaar op dit moment, maar ik hoor jou en steun jou." We zijn allemaal moe, maar blijf naar elkaar luisteren.'

\section{Hoe kun je je als zorgmedewer-} ker of verpleegkundige opstellen in deze pandemie?

Mooy: 'Ik denk dat je zelf zoveel mogelijk moet denken vanuit preventie. Dat betekent dat je ervoor moet gaan staan niet onbeschermd te willen werken.' Ipenburg vult aan: 'In de eerste golf wisten we niet wat ons overkwam en stonden we allemaal strak van de adrenaline. Er werd gehandeld vanuit een 'niet weten' en er kwamen stroomschema's met wat te doen als er onvoldoende beschermingsmiddelen waren. Maar ze hadden ons moeten opdragen: niet werken zonder beschermingsmiddelen. Want daar hebben we nu nog last van. We legden de beelden van Wuhan en Italië naast ons neer. Dat is geen verwijt, want daar wilde niemand aan. Het voelde alsof er geen andere keuze was dan in het onbekende diepe te springen. Er was onvoldoende voorbereiding. $\mathrm{Nu}$ we 8 maanden verder zijn, is het tijd om dingen terug te draaien. Zoals de situatie rond die beschermingsmiddelen. We moeten af van het idee dat chirurgische maskers in de zorg voor covid-patiënten volstaan.' Volgens Ipenburg krijgen verpleegkundigen ook te weinig informatie en voorlichting van de overheid over de ziekte covid-19 zelf en de besmettelijkheid ervan. 'En dan voel je de dreiging ook minder.'

Voorlichting over covid-19 of voorlichting aan verpleeglkundigen?

Mooy: 'Verpleegkundigen hebben een grote rol in de voorlichting over covid-19, maar preventie begint met goede voorlichting aan verpleegkundigen zelf.' Volgens Mooy schiet de overheid hierin ook tekort. 'Als je als regering verpleegkundigen laat blootstaan aan het virus, dan moet je ze ook voldoende beschermen. Ik heb mij verbaasd over de gelatenheid waarmee verpleegkundigen onveilig hebben gewerkt of nog altijd werken. En ze organiseren zich ook niet om zich hiertegen te verzetten. Ik begrijp dat echt niet, ook niet als dat betekent dat je tegen je leidinggevende moet ingaan of dat je niet meer loyaal kunt zijn tegenover patiënten of cliënten. Binnen en buiten covid-tijd moet de beroepsgroep gaan zorgen voor $100 \%$ bescherming. Het is niet te verkroppen dat je geen normaal mondneusmasker tot je beschikking hebt. Je moet echt op gaan staan en zeggen: nee, wij werken niet zonder beschermingsmiddelen. Ook al zegt het RIVM dat het wel kan. Vind je het gek dat het gevoel van urgentie ontbreekt. Uit ervaring weet ik dat zorgmedewerkers een sterk verantwoordelijkheidsgevoel hebben om gewoon te blijven werken. Voor velen ligt hun hart in de zorg voor anderen en dat is heel mooi. Maar zorg dan eerst goed voor jezelf. En dat moet je nu afdwingen, in het belang van jezelf en van je patiënten. Je moet je ervan bewust zijn dat jij een besmetting kunt oplopen die je verder kunt verspreiden. Onder zorgmedewerkers zijn er ook veel die het 'maar een griepje' vinden. Dat levert gevaarlijke situaties op. Ook voor je collega's.'

\section{Welke rol spelen verpleegkun- digen bij de voorlichting over covid-19? \\ Ipenburg: 'Eerst moet het besef doordrin- gen dat $e l k$ werkveld binnen de zorg een rol heeft in preventie. Dat begint bij met elkaar het gesprek aangaan. Preventie is gericht op elkaar gezond houden en dus voorkomen dat patiënten besmet raken. Je maakt het verschil door een dialoog te voeren over wat een besmetting nu eigen- lijk inhoudt. Wat kan je eraan doen om de besmetting te voorkomen, welke bar- rières liggen er bij de ander om zich aan}




\section{'Covid heeft niets nieuws gebracht, maar legt alleen pijnlijk de problemen bloot die er al waren in de zorg'}

de leefregels te houden? Als de patiënt eenmaal in het ziekenhuis ligt, is het voor hem misschien te laat, maar niet voor zijn naasten en andere niet-covid-patiënten. Maak het virus zichtbaar met woorden.'

We zien steeds meer agressie rond covid-zorg; hoe gaan verpleegkundigen daarmee om? Ipenburg: 'Dit is een ontzettend moeilijk onderwerp, dat veel meer aandacht verdient. Mensen zijn moe, boos, verdrietig en voelen zich machteloos, net als wij. Bedenk dat veel boosheid voortkomt uit onmacht en onduidelijkheid. Blijf rustig en blijf met gepaste waakzaamheid luisteren, ook als de ander boos is. Stel je vragend op en zorg dat je niet alleen bent. Actie en handelen komen later wel.'

\section{Daarnaast is de werkdruk hoog} en loopt oolk de morele stress op... Ipenburg: 'Ja, dat is zwaar. Zorg dat je je grenzen aanvoelt en probeer er niet structureel overheen te gaan. Het is soms moeilijk, maar "nee" is ook een antwoord. Je mag jezelf ziek melden, helemaal als je weet dat je daarmee misschien wel een besmettingscirkel doorbreekt of als je weet dat je anders niet meer kunt functioneren. Er liggen zoveel lasten op onze schouders, dus de concentratie is heel hard nodig. Al lijkt het misschien een dooddoener: bewegen, gezond eten en (heel belangrijk) voldoende slaap zijn essentieel om overeind te blijven. Daarnaast gun ik iedereen covid-vrije momenten, kleine, fijne momentjes met je gezin of jezelf en naasten ter ontspanning. Ik weet als geen ander hoe moeilijk het is, toch merk ik dat het die geluksmomentjes zijn die me overeind houden.'

Is er nog wel een weg terug uit deze benarde situatie?

Mooy: 'Het kabinet zou de komst van het vaccin kunnen aangrijpen om de strategie te veranderen. Zowel het RIVM als het kabinet ziet het vaccin als de heilige graal, en een uitweg uit deze ellende, maar dat klopt niet met de werkelijkheid. We weten nog niet eens of het wel groepsimmuniteit biedt. En dat moet je ook als zodanig melden: het vaccin biedt preventie en daarmee kunnen we makkelijker naar een samenleving zonder corona toewerken.' Ipenburg: 'Om dit besef ook bij verpleegkundigen aan te wakkeren is het heel belangrijk om ook hen voor te lichten over het vaccin en mee te nemen in de strategieën die er liggen. Dus niet alleen roepen dat we verplicht zijn om ons te laten inenten en dreigen met baanverlies, maar echt mee laten denken in de strategie zelf en de kennis die er ligt over het vaccin.'

Helaas heb je als verpleeglkundige niet direct invloed op de strategie en communicatie van het kabinet. Hoe blijf je zelf staan in deze moeilijke tijd? Ipenburg: 'Verpleegkundigen zijn onderdeel van de samenleving. Wij hebben onze heldencape opgehaald en dragen de lasten, en moeten dat ook nog eens waardig doen. Doordat de maatschappij ons positioneerde als helden werden we voor het blok gezet. Maar zet je eigen gezondheid altijd voorop en zorg dat je voldoende rust neemt. Besef dat we nog heel lang in deze situatie zitten, dat je niet ongestraft alsmaar kunt overwerken en jezelf in de vermoeidheid kunt draaien. Want hoe vermoeider je bent, hoe meer regels je gaat loslaten. Het continu voelen van machteloosheid kan leiden tot depressie. Trek dan aan de bel. Zorg voor elkaar.'

\section{Noot}

1 Een 'rood' team is een groep die een organisatie (het 'blauwe' team) helpt om zichzelf te verbeteren door kritisch naar haar beleid te kijken. (www.en.wikipedia.org)

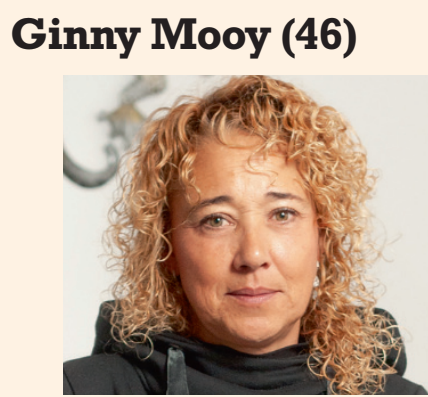

2016-heden Onderzoeker en antropoloog, eigen bureau Socioscience

2006-2016 Directeur Stichting Mind To Change

2014-2015 Directeur Stichting Kick Ebola

2006 Msc Culturele Antropologie \& Sociologie niet-Westerse samenlevingen. Bacc. Culturele Antropologie \& Sociologie niet-Westerse samenlevingen

2002 Propedeuse Maatschappelijk Werk en Dienstverlening

1996 HBO Financieel Management

\section{Nienke Ipenburg (38)}

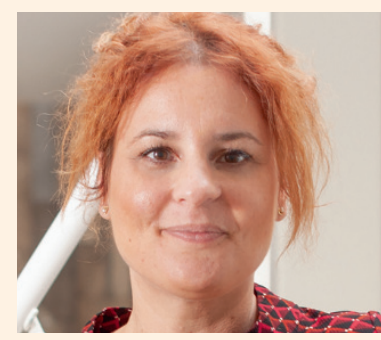

2017 - heden verpleegkundig specialist binnen de huisartsenzorg Rotterdam

2011-2017 Verpleegkundige specialist maag darm lever Leids Universitair Medisch Centrum

2010 Master advanced nurse practice 2008 -2011 verpleegkundig consulent maag darm lever periferie / in opleiding tot verpleegkundig specialist Haarlem, Kennemergasthuis

2000 - HBO-V duaal Jeroen Boschziekenhuis, Den Bosch 